\section{COMBUSTION STUDY OF WASTE COOKING OIL BIODIESEL IN AN OIL BURNER}

Nik Nur Fatin Amiera Nik Aziza, Mazlan Saidb, Muhammad Syahiran Abdul Malika, Mohammad Nazri Mohd Ja'afara,b*, Norazila Othmana, Mohd Kamal Ariffina, Mohd Faizal Hassana

aSchool of Mechanical Engineering, Faculty of Engineering, Universiti Teknologi Malaysia, 81310 UTM Johor Bahru, Johor, Malaysia

bInstitute for Vehicle Systems and Engineering, 81310 UTM Johor Bahru, Johor, Malaysia
Article history

Received

11 June 2019

Received in revised form

14 May 2020

Accepted

21 May 2020

Published online

22 June 2020

*Corresponding author nazri@mail.fkm.utm.my

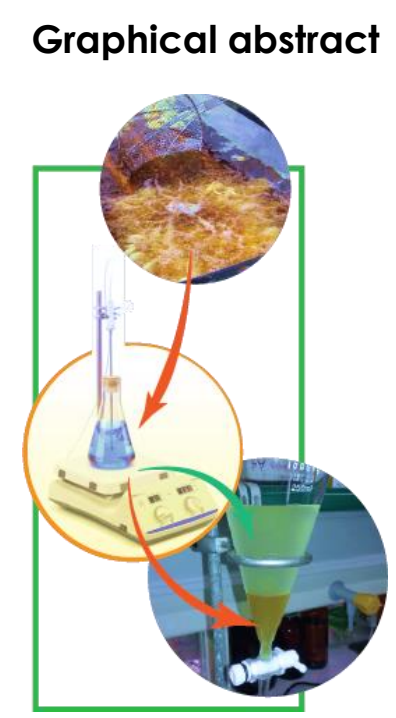

\begin{abstract}
Depletion of fossil fuels, concerns on environment, and fuel price fluctuation have become the major drives in searching for sustainable alternative fuel. In that regard, a study was conducted to evaluate the combustion performance of Waste Cooking Oil (WCO) converted into biodiesel and blended with Conventional Diesel Fuel (CDF) as a mean of sustainable replacement for diesel fuel. In this study, the production of biodiesel fuel from waste cooking oil was done via transesterification process, using the single step approach. The properties of the WCO biodiesel was characterized. The combustion performance of the produced fuels has been studied for B10 and B30 biodiesel from WCO and CDF (as baseline) based on their wall temperature profiles and gaseous emissions generated such as nitrogen oxides $\left(\mathrm{NO}_{\mathrm{x}}\right)$, carbon monoxide (CO) and sulphur dioxide $\left(\mathrm{SO}_{2}\right)$. It was found that the B30 WCO biodiesel emits lower emission compared to CDF but at the same time generates a lower temperature profile.
\end{abstract}

Keywords: Transesterification, waste cooking oil, oil burner, emission, $\mathrm{NO}_{x}$

\begin{abstract}
Abstrak
Bekalan bahan api fosil yang semakin berkurangan, kebimbangan terhadap alam sekitar, dan turun naik harga bahan api telah menjadi pemacu utama dalam mencari bahan bakar alternatif yang mampan. Sehubungan dengan itu, satu kajian telah dijalankan untuk menilai prestasi pembakaran minyak masak terpakai (WCO) yang diproses menjadi biodiesel dan diadun dengan bahan api diesel konvensional (CDF) sebagai sumber pengganti lestari minyak diesel. Dalam kajian ini, penghasilan bahan api biodiesel dari minyak masak terpakai dilakukan melalui kaedah transesterifikasi, menggunakan pendekatan langkah tunggal. Sifat-sifat biodiesel WCO diukur. Prestasi pembakaran bahan api biodiesel B10 dan B30 daripada WCO dan CFD (sebagai bahan api garis dasar) yang dihasilkan telah dikaji berdasarkan profil suhu dinding dan pelepasan gas emisi yang dijana seperti oksida nitrogen $\left(\mathrm{NO}_{\mathrm{x}}\right)$, sulfur dioksida $\left(\mathrm{SO}_{2}\right)$ dan karbon monoksida (CO). Daripada hasil Ujikaji, didapati bahawa biodiesel WCO B3O menjana pelepasan emisi terendah berbanding dengan CDF tetapi pada masa yang sama menghasilkan profil suhu yang lebih rendah.
\end{abstract}

Kata kunci: Transesterifikasi, minyak masak terpakai, pembakar minyak, emisi, $\mathrm{NO}_{x}$

(C) 2020 Penerbit UTM Press. All rights reserved 


\subsection{INTRODUCTION}

The world is facing a menacing state of fossil fuels depletion and environmental deterioration. This is the consequence of the rising demands in energy usage throughout the world, including the developing nations. Various measures have been implemented to compensate the environmental pollution and depletion of fossil fuel. The most desired solution is by the use of alternative renewable fuels. Biodiesel is comparable to ordinary diesel and is almost similar in term of engine performance, but it produces less emission of unburnt hydrocarbon, less particulate matter and it is renewable [1]. Biodiesels or also known as methyl ester fatty acids are derived from vegetable oils and animal fats which are renewable lipids feedstock. There are various feedstocks such as chicken fat, beef tallow, soybean oil, rapeseed oil, canola oil, palm oil, jatropha oil, and waste cooking oil which have been studied as biodiesel [2]. The important criteria to be considered when selecting for feedstock are cost and availability and it differs based on location and climate. For example, the common use of soybean oil in the United States of America and rapeseed oil in Germany as feedstock for biodiesel production is due to the availability of the feedstock [3]. In this study, waste cooking oil is chosen as feedstock due to its high availability and low cost. Utilizing waste cooking oil as feedstock in biodiesel production minimizes the environmental harms that are caused by disposing it into the ecosystem [4].

The combustion performance of biodiesel is strongly associated to its physical properties and chemical composition. For instance, the fuel physical properties such as density and kinematic viscosity can affect the fuel combustion in the chamber caused by poor atomization of fuel [5]. Utilization of $100 \%$ pure biodiesel in a diesel engine require some engine modification to prevent damage to the engine components. Accordingly, blending biodiesel with petroleum diesel fuel could avoid engine modification and enhance the properties of the biodiesel blends, as well as improving the combustion performance.

The combustion of fossil fuel releases hazardous emissions. These gaseous emissions deteriorate the environment quality and thus risking the human health. For instance, $\mathrm{NO}_{x}$ at high emission level contributes to the production of photochemical smog at ground level and activates acid rain which could damage plant lives. The application of biodiesel blends has shown significant results in the reduction of harmful gaseous emissions. A study has been conducted using biodiesel blends in a single cylinder, 4 stroke diesel engine and the results show appreciable reduction of $\mathrm{CO}, \mathrm{UHC}$, and $\mathrm{NO}_{x}$ emissions [6].

In this study, WCO biodiesel is produced through transesterification technique. It is then blended with petroleum diesel in different percentages, i.e. B10 and B30 where the number denotes the volume percentage of WCO biodiesel in the blend (meaning, B 10 consists of $10 \%$ WCO biodiesel by volume in $90 \%$ of diesel). The aim of the study is to investigate the performance of the biodiesel, physically and during combustion. Thus, the characteristics of physical properties such as density, specific gravity, kinematic viscosity, calorific value, and surface tension were measured for WCO biodiesel and the blends. Combustion tests were performed for all fuel blends including diesel fuel at equivalence ratio of $0.8,1.0$, and 1.2. The wall temperature during combustion and the gaseous emissions at the exhaust were measured.

\subsection{METHODOLOGY}

\subsection{Fuel Production}

The waste cooking oils (WCO) used in the transesterification process were obtained from food stalls. The transesterification process was conducted because it is one of the cheapest methods and produces very high yield. The transesterifications process can be divided into three stage processes. They are the pre-treatment process, the transesterification process, and the post-treatment process. In the pre-treatment process, WCO was heated at $100^{\circ} \mathrm{C}$ and is stirred for 1 hour to remove any moisture. Then the WCO was mixed with different composition of potassium hydroxide (KOH) and methanol as shown in Table 1 to produce WCO biodiesel and glycerol. In the post-treatment process, the glycerol formed at the bottom layer was removed and the WCO biodiesel underwent the washing process using distilled water at $50^{\circ} \mathrm{C}$ at various intervals to remove any impurities and the remaining glycerol. Finally, the WCO biodiesel was reheated for 30 minutes and is stirred to remove any remaining water. The final product is a refined WCO biodiesel and the amounts of yield for each set of conditions are recorded in Table 1.

The highest yield was obtained at production parameters of $0.8 \% \mathrm{w} / \mathrm{w}$ of $\mathrm{KOH}$ with $4 \%$ of methanol (25\% v/v) at $40^{\circ} \mathrm{C}$. It produced WCO biodiesel at $88.6 \%$ yield.

Table 1 Parameters and yield of biodiesel for optimization

\begin{tabular}{cccc}
\hline $\begin{array}{c}\text { Potassium } \\
\text { hydroxide } \\
\mathbf{\%}(\mathbf{w} / \mathbf{w})\end{array}$ & $\begin{array}{c}\text { Methanol } \\
(\mathbf{2 5} \mathbf{\%} / \mathbf{v})\end{array}$ & $\begin{array}{c}\text { Temperature } \\
\left({ }^{\circ} \mathbf{C}\right)\end{array}$ & $\begin{array}{c}\text { Biodiesel } \\
\text { Yield }(\%)\end{array}$ \\
\hline 2 & 12 & 40 & 87.6 \\
2 & 4 & 40 & 76.5 \\
0.8 & 12 & 40 & 88.1 \\
$\mathbf{0 . 8}$ & $\mathbf{4}$ & $\mathbf{4 0}$ & $\mathbf{8 8 . 6}$ \\
2 & 12 & 65 & 78.4 \\
0.8 & 12 & 65 & 87.2 \\
2 & 4 & 65 & 50.0 \\
0.8 & 4 & 65 & 69.3 \\
\hline
\end{tabular}




\subsection{Physical Properties of the Fuel Blends}

The fuel used in the experiment was Conventional Diesel Fuel (CDF) obtained from PETRONAS petrol station. The neat WCO biodiesel (B100) is mixed with CDF to produce B10 and B30 biodiesel blends. A sample of each fuel blend was taken to determine its physical properties in terms of density at room temperature, kinematic viscosity at $40^{\circ} \mathrm{C}$, calorific value, acid value and surface tension. The volume and properties of diesel, WCO biodiesel and their blends (B10 and B30) are given in Table 2.

Table 2 Fuel Properties

\begin{tabular}{ccccc}
\hline \multirow{2}{*}{ Properties } & \multicolumn{5}{c}{ Blends } \\
\cline { 2 - 5 } & $\mathrm{B} 0$ & $\mathrm{~B} 10$ & $\mathrm{~B} 30$ & $\mathrm{~B} 100$ \\
\hline $\begin{array}{c}\text { Density }\left(\mathrm{g} / \mathrm{cm}^{3}\right) \\
\text { Kinematic Viscosity, } \\
\text { @ 40 } \mathrm{C}\left(\mathrm{mm}^{2} / \mathrm{s}\right)\end{array}$ & 0.837 & 0.841 & 0.859 & 0.874 \\
$\begin{array}{c}\text { Calorific Value (J/g) } \\
\text { Acid Value (mg } \\
\text { KOH/g) }\end{array}$ & 45833 & 44938 & 44293 & 39777 \\
$\begin{array}{c}\text { Surface Tension } \\
\text { (mN/m) }\end{array}$ & 0.421 & 0.561 & 0.631 & 0.771 \\
$\begin{array}{c}\text { WCO Biodiesel } \\
\text { Volume (L) }\end{array}$ & 0 & 31.6 & 32.2 & 33.1 \\
Diesel Volume (L) & 10 & 9 & 7 & 0 \\
\hline
\end{tabular}

\subsection{Combustion Experimental Set-up}

Figure 1 shows the schematic of the experimental setup for the combustion test. The set-up includes a Baltur BT14 fuel oil burner with standard spray nozzle, type-K thermocouples with maximum temperature of $1200^{\circ} \mathrm{C}$, a Midi temperature data logger, a $1000 \mathrm{~mm}$ length open-ended combustion chamber, a Horiba Enda 5000 gas analyser and an air speed indicator.

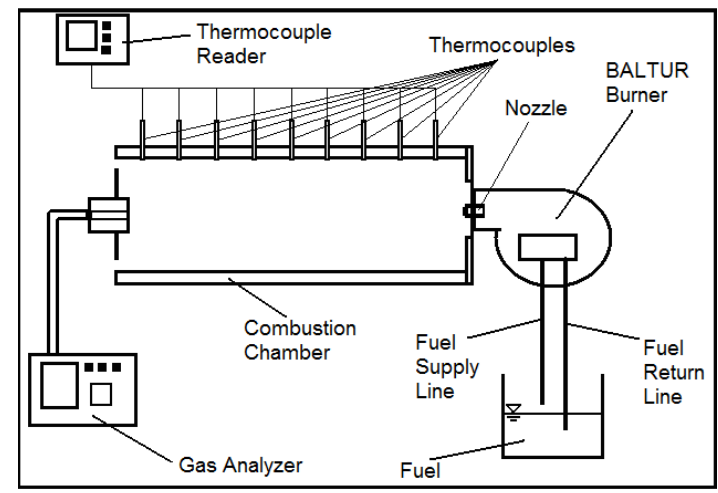

Figure 1 Schematic diagram of the combustion test set-up

The burner was placed at the inlet of the combustion chamber to blow the mixed air and fuel before igniting the mixture. The combustion chamber fitted with eight thermocouples were placed at the top surface. The distance between each thermocouple is at $100 \mathrm{~mm}$ apart. They are connected to the temperature data logger. These thermocouples transformed heat to the electric signal which in turn will convert the signal into temperature values along the combustion chamber wall. The Steinen standard nozzle, with spray angle of $45^{\circ}$ and flow rate of 1.5 $\mathrm{gal} / \mathrm{h}$ was fixed near the inlet to spray the fuel into the combustion chamber. To collect emission data of combusted fuel, an emission ducting was attached to the open end of the combustion chamber that channelled the emission gas to the emission sensors in the gas analyser. Through the electrical signal from the sensors of emission, the gas analyser processes the signal and display the level of emissions such as $\mathrm{NO}_{x}$, $\mathrm{SO}_{2}$ and $\mathrm{CO}$. Three different equivalence ratios used in this experiment were indicated by $0.8,1.0$ and 1.2. The equivalence ratio of 1.0 indicates the stoichiometry mixture. The lean mixture is indicated by equivalence ratio of 0.8 where there is less fuel than air in the mixture. Whereas, a rich mixture is indicated by equivalence ratio of 1.2, where there are more fuel than air in the combustible mixture. To measure the amount of fuel and air mixed in the combustion chamber during the combustion process, an airflow meter and a fuel flow meter is used.

\subsection{RESULTS AND DISCUSSION}

\subsection{Fuel Properties}

Sizes of the molecules of biodiesel and petroleum diesel are slightly similar. However, it differs in the chemical structure. The results for the differences in physical properties of all tested fuels also contributed to differences in chemical composition and structure [7].

Neat WCO (B100) shows lower calorific value compared to the commercial diesel as shown in Table 2. That means the commercial diesel has more energy contains in the fuel for the same mass compared to neat WCO. Other important parameters of fuel properties are kinematic viscosity, density and surface tension show high in value for neat WCO. These properties will cause poor vaporisation of fuel during the injection stage. This in turn will cause the fuel to be difficult to atomise to a size that can vaporise accordingly which may easily be combusted in the burner, hence leading to carbon deposits build up after the combustion [8]. These values decrease when more commercial diesel is added to the neat WCO in the blends.

The higher value of surface tension in biodiesel will cause in difficulty to form the droplet and resulted in larger droplets size [9]. Hence, it can be concluded that WCO with higher surface tension, that is more viscous and denser than commercial diesel fuel, resulted in low energy content. 


\subsection{Wall Temperature}

The key issues with the combustor are wall temperature that shows the effectiveness of energy distribution during the combustion occurring in the combustion chamber. From the profile that was measured at different locations with different fuel blends and equivalence ratios of 0.8 to 1.0 then 1.2, the effect the wall temperature profile shows similar pattern, however, with different peak value in temperature. It is clearly shown in Figure 2.

It shows that the temperature increases from the distance of $0.1 \mathrm{~m}$ until it reaches $0.3 \mathrm{~m}$ from the burner and then decreases after $0.3 \mathrm{~m}$ till the end of the combustion chamber. The highest temperature was recorded at the distance of $0.3 \mathrm{~m}$ from entrance of the combustion chamber. The conditions at this point indicate that the air and fuel are homogenously mixed and combusted together to produce the highest temperature. At the distance of $0.3 \mathrm{~m}$ from the burner exit, it shows the primary zone of combustion and causing the temperature to reach the maximum value.

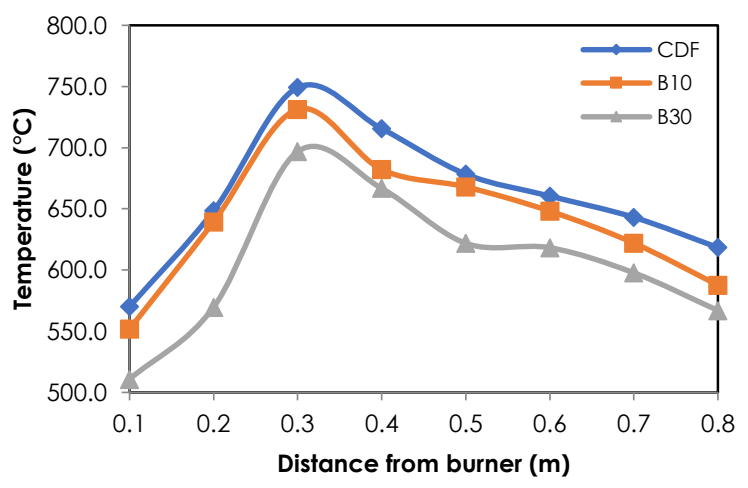

(a)

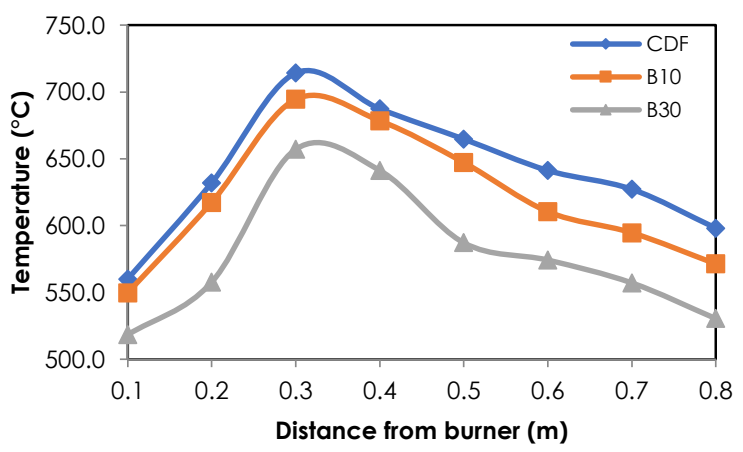

(b)

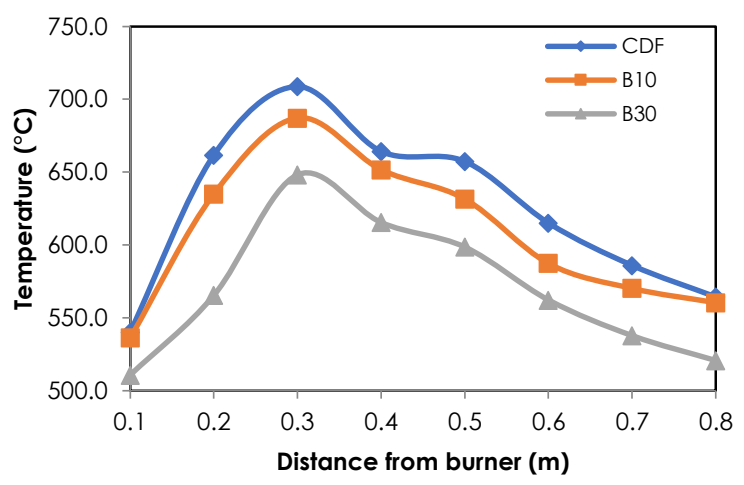

(c)

Figure 2 The temperature profiles for all fuels at different equivalence ratios, (a) fuel lean mixture; (b) stoichiometry; (c) fuel rich mixture

Afterwards, it shows the dilution zone where the temperature starts to drop slightly [10]. For each equivalence ratio, CDF shows the highest wall temperature then followed by B10 and finally B30. At stoichiometric condition, CDF has the maximum value of $714.3^{\circ} \mathrm{C}$ followed by $\mathrm{B} 10$ and $\mathrm{B} 30$ with the maximum values of $684.3^{\circ} \mathrm{C}$ and $657.1^{\circ} \mathrm{C}$, respectively. There is a temperature reduction of $19.8 \%$ between CDF and B30 while for $\mathrm{B} 10$ and $\mathrm{B} 30$, the temperature reduction is $37.4 \%$.

Theoretically, as the volumetric percentage of WCO increases, the calorific value decreases. This is causing the wall temperature to decrease as the percentage volume of WCO increased from B10 to B30 [11].

\subsection{NO Emission}

Figure 3 shows the emission concentrations of $\mathrm{NO}_{x}$ for each blend and CDF at different equivalence ratios. It shows that the emission increases from the lean mixture to stoichiometric mixture and start to decrease as it passes this point. NOx emission decreases when more $\mathrm{WCO}$ is added into the commercial diesel. However, the equivalence ratio also contributes to the $\mathrm{NO}_{x}$ reduction. This happens during oxygenation of biodiesel that combust at a lower temperature, thus reducing the thermal formation of $\mathrm{NO}_{x}$. From the study that had been done, it shows that the formation of $\mathrm{NO}_{x}$ is mainly from high-temperature combustion process since nitrogen is the main component of the air [12]. 


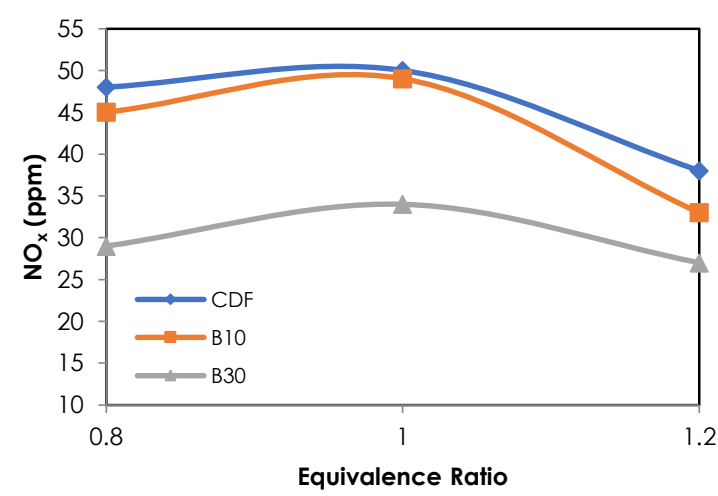

Figure $3 \mathrm{NO}_{x}$ emission versus equivalence ratio

\section{$3.4 \mathrm{SO}_{2}$ Emission}

Figure 4 shows that all fuels exhibit the same trend; that is the emission of $\mathrm{SO}_{2}$ increases as the equivalence ratios increases. The amount of fuel increases the combustion of fuel, which in turn allows more sulphur in the fuel to react with oxygen to produce $\mathrm{SO}_{2}$. At equivalence ratio, $\phi=0.8, \mathrm{~B} 30$ records the lowest emissions of $\mathrm{SO}_{2}$ which is $10 \mathrm{ppm}$ compared to $\mathrm{B} 10$ and diesel which are $15 \mathrm{ppm}$ and $16 \mathrm{ppm}$ respectively. This happens because biodiesel contains less sulphur than diesel hence released less $\mathrm{SO}_{2}$ [13].

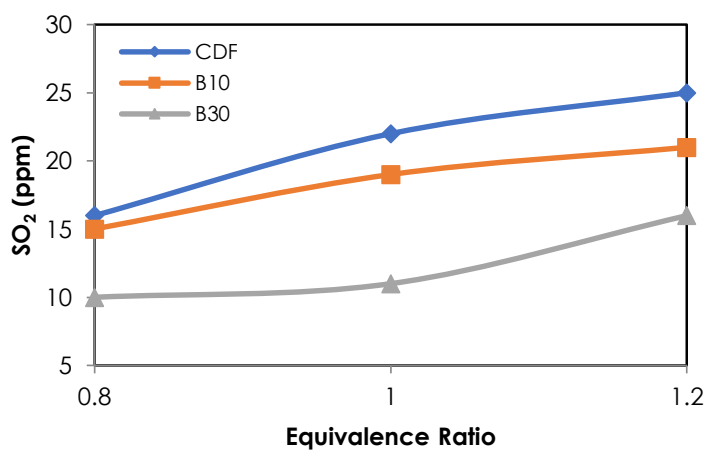

Figure $4 \mathrm{SO}_{2}$ emission versus equivalence ratio

\subsection{CO Emission}

Figure 5 shows a really high emission of $\mathrm{CO}$ gases at equivalence ratio of 1.2 for all blends. The formation of $\mathrm{CO}$ is mainly in the region where there is fuel rich mixtures. This is because, in this region, the combustion is usually incomplete due to lack of oxygen to achieve complete combustion, hence enhancing the formation of $\mathrm{CO}$. Incomplete combustion will occur when there is not enough oxygen supply during the combustion. The carbon contained in the fuel will react with less oxygen in the air to form CO [14]. B30 blend shows the lowest emission of $\mathrm{CO}$ which is 154 ppm compared to $\mathrm{CO}$ emitted by CDF and $\mathrm{B} 10$ which are $220 \mathrm{ppm}$ and $218 \mathrm{ppm}$ respectively at equivalence ratio, $\phi=1.0$. Biodiesel has more oxygen content than CDF, thus promotes this effect. It had been discussed in theory that biodiesel can combust more completely in the locally fuel-rich region and demonstrates that the reduction in emission could occur [15].

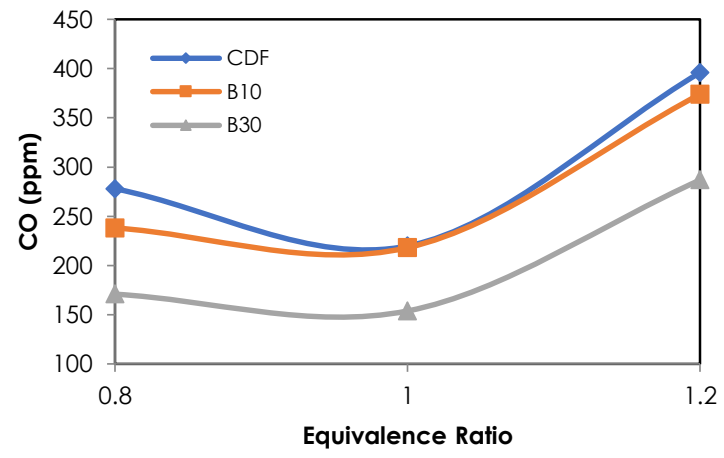

Figure 5 CO emission versus equivalence ratio

\subsection{CONCLUSION}

As a conclusion, Waste Cooking Oil (WCO) can be converted to biodiesel with acceptable difference in physical properties compared to Commercial Diesel Fuel (CDF) and it can be added to CDF as a blend. The blend can increase the combustion quality of WCO and at the same time reduces emission produced by CDF. The results indicated that, by increasing the WCO biodiesel content in diesel blend, the density, surface tension and kinematic viscosity increased while the calorific value decreased. The chemical composition of WCO biodiesel altered the fuel properties of diesel, which resulted in the WCO biodiesel to have different fuel properties. The increase of WCO biodiesel content in the blend reduces the emissions of $\mathrm{NO}_{x}, \mathrm{SO}_{2}$ and $\mathrm{CO}$ and also reduces the wall temperature. For all equivalence ratios, the WCO biodiesel blends were combusted at lower temperature than CDF.

\section{Acknowledgement}

The authors would like to thank the Ministry of Higher Education of Malaysia and Research Management Centre, Universiti Teknologi Malaysia (project number: 4F976) for the research grant to undertake this project. The authors would also like to thank the School of Mechanical Engineering, Faculty of Engineering, Universiti Teknologi Malaysia for providing the research facilities and space to undertake this work. 


\section{References}

[1] Shirneshan, A. 2013. $\mathrm{HC}, \mathrm{CO}, \mathrm{CO}_{2}$ and $\mathrm{NO}_{x}$ Emission Evaluation of a Diesel Engine Fueled with Waste Frying Oil Methyl Ester. Energy Procedia. 75: 292-297.

[2] Issariyakul, T., Dalai, A. K. 2014. Biodiesel from Vegetable Oils. Renewable and Sustainable Energy Reviews. $31(3)$ : 446-471.

[3] Huang, D., Zhou, H., Lin, L. 2012. Biodiesel: An Alternative to Conventional Fuel. Energy Procedia. 16: 1874-1885.

[4] Abdul Raqeeb M. 2015. Biodiesel Production from Waste Cooking Oil. Journal of Chemical and Pharmaceutical Research. 7(12): 670-681.

[5] Yasin, M. H. M., Mamat, R., Yusop, A. F. et al. 2013. Fuel Physical Characteristics of Biodiesel Blend Fuels with Alcohol as Additives. Energy Procedia. 53: 701-706.

[6] Attia, A. M. A., Hassaneen, A. E. 2015. Influence of Diesel Fuel Blended with Biodiesel Produced from Waste Cooking Oil on Diesel Engine Performance. Fuel. 167: 316328.

[7] Verma, P. and M. Sharma. 2016. Review of Process Parameters for Biodiesel Production from Different Feedstocks. Renewable and Sustainable Energy Reviews. 62: 1063-1071.

[8] Ciolkosz D. 2015. What's So Different about Biodiesel Fuel? Bioenergy. 551-555.

[9] Campus P. 2011. Comparative Analysis of Fuel Characteristics of Bio-diesel Produced from Selected Oil- bearing Seeds in Nigeria. European Journal of Scientific Research. 58: 238-246.

[10] Hwang, J., C. Bae, and T. Gupta. 2016. Application of Waste Cooking oil (WCO) Biodiesel in a Compression Ignition Engine. Fuel. 176: 20-31.

[11] Rahim M. R. and M. N. M. Ja'afar. 2015. Kesan Sudut Pusaran Terhadap Pembakaran Menggunakan Pemusar Jejarian Dwi Aliran. Jurnal Teknologi. 77(8): 37-45.

[12] Jha, S. K. and S. Fernando. 2007. Flame Temperature Analysis of Biodiesel Blends and Components. ASABE Annual International Meeting, Minneapolis, MN. June 1720. Paper \# 076234.

[13] Lapuerta M., O. Armas, and J. Rodriguez-Fernandez. 2008. Effect of Biodiesel Fuels on Diesel Engine Emissions. Progress in Energy and Combustion Science. 34: 198-223.

[14] Sawarimuthu S. and M. N. M. Ja' afar. 2008. Performance of Various Biofuel Blends on Burner System. Jurnal Mekanikal. 27: 69-77.

[15] Lim Y. C. and H. K. Suh. 2016. Prediction of Biodiese Combustion, $\mathrm{co}$ and $\mathrm{NO}_{x}$ Emission Characteristics in Accordance with Equivalence Ratio. Journal of the Korean Society of Combustion. 21: 1-7.

[16] Jaafar M. N. M. and S. Safiullah. 2018. Combustion Characteristics of Rice Bran Oil Biodiesel in an Oil Burner. Jurnal Teknologi. 80(3): 185-192. 